\title{
Envisioning a national invasive species information framework
}

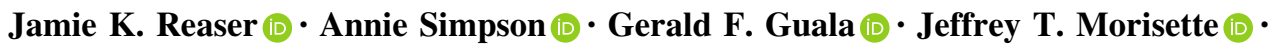 \\ Pam Fuller (D)
}

Received: 3 November 2019/Accepted: 3 November 2019/Published online: 31 December 2019

(C) The Author(s) 2019

\begin{abstract}
With a view toward creating a national Early Detection and Rapid Response Program (EDRR) program, the United States National Invasive Species Council Management Plan for 2016-2018 calls for a series of assessments of federal EDRR capacities, including the evaluation of "relevant federal information systems to provide the data and other information necessary for risk analyses/horizon scanning, rapid specimen identification, and rapid response planning." This paper is a response to that directive. We provide an overview of information management needs for enacting EDRR and discuss challenges to meeting these needs. We then review the history of relevant US policy directives for advancing
\end{abstract}

J. K. Reaser $(\square)$

Center for Large Landscape Conservation, $303 \mathrm{~W}$

Mendenhall St \#4, Bozeman, MT 59715, USA

e-mail: jamiekreaser@gmail.com

\section{A. Simpson - G. F. Guala}

US Geological Survey, 12201 Sunrise Valley Dr.,

Mailstop 302, Reston, VA 20192, USA

\section{J. T. Morisette}

National Invasive Species Council Secretariat, c/o National Park Service, 1201 Oakridge Drive, Fort Collins, CO 80525, USA

\section{P. Fuller}

Wetlands and Aquatic Research Center, US Geological Survey Emeritus, Nonindigenous Aquatic Species Program, 7920 NW 71st Street, Gainesville, FL 32653, USA invasive species information systems and provide an overview of federal invasive species information system capacities, including current gaps and inconsistencies. We conclude with a summary of key principles and needs for establishing a national invasive species information framework. Our findings are consistent with earlier studies and, thus, emphasize the need to act on long-recognized needs. As a supplement to this paper, we have cataloged federal invasive species databases and information tools identified through this work.

Keywords Invasive species - Early detection and rapid response (EDRR) - Information systems · Data infrastructure $\cdot$ Federal capacities

\section{Introduction}

The early detection of and rapid response to invasive species (EDRR) is considered a guiding principle for minimizing the impact of invasive species in an expedited yet effective and cost-efficient manner (Reaser et al. 2019a). With a view toward creating a national EDRR program, the United States National Invasive Species Council (NISC) Management Plan for 2016-2018 calls for a series of assessments of federal EDRR capacities, including the evaluation of "relevant federal information systems to provide the 
data and other information necessary for risk analyses/ horizon scanning, rapid specimen identification, and rapid response planning" (NISC 2016). This paper is one of five assessment outputs responding to the Management Plan directive with regard to federal information management system capacities. Wallace et al. (2018) provide a broad overview of responses to a federal survey of information system capacities, which is discussed later in this paper. Martinez et al. (2019, this issue) include information technology capacities and needs as identified via a federal survey. Wallace et al. (2019, this issue) provide guidance for improving access to and analysis of invasive species information. As a complement to our paper, Simpson et al. (2019) have published the first catalog of databases and information tools key to the establishment of a national EDRR program.

EDRR is dependent on the ready availability of high-quality information at every stage in the process (Reaser et al. 2019a, this issue). Following the EDRR framework proposed by Reaser et al. (2019a Figure 1, this issue), practitioners need easy access to information that enables them to establish the legal and institutional frameworks that enable EDRR planning and enactment (Burgos-Rodríguez and Burgiel 2019a, b, this issue), develop effective and costefficient decision support tools (Meyers et al. 2019, this issue; Morisette et al. 2019, this issue), intercept non-native organisms, and accurately and quickly identify the organism(s) (Lyal and Miller et al. 2019, this issue). They also need the capacity to report the authoritatively identified organisms to appropriate decision-makers, and then to the decision implementer(s) in a relatively short amount of time (see Reaser et al. 2019a, this issue, for discussion on "rapidness"). Information is also necessary to support institutional and programmatic planning (Burgiel 2019, this issue), for the development and appropriate application of the various technologies (Martinez et al. 2019, this issue), and for skills training applied during EDRR enactment (Burgiel 2019, this issue).

While the need for accurate, readily accessible information to support EDRR may be conceptually obvious, it has thus far proven challenging to establish invasive species information systems that effectively serve the needs of policy and management decisionmakers at national and regional scales over the long term (Ridgway et al. 1999; Ricciardi et al. 2000;
Fornwall and Loope 2004; Graham et al. 2008). The reasons for this are multiple:

Type of data collected and reported. Until recently, biodiversity data collection and reporting has largely focused on information relevant to native species. Non-native species were often excluded from biodiversity inventory, monitoring, and research initiatives and thus data on occurrence outside of the native range, biology in novel environments, and observable impacts were not included as information fields in biodiversity datasets (Simpson 1964).

Data sharing concerns. There are numerous reasons why there is resistance to making species-locality data publicly available, and limits to data sharing may be one of the most substantial challenges to enacting a well-integrated information framework (Jarnevich et al. 2007). For example, in the context of threatened and endangered species, there are concerns that rare species would be collected for illegal trade or destroyed to avoid regulatory restrictions on land management (Ruhl 1998; Lueck and Michael 2003). With regard to non-native species data, the private sector may have concerns about protecting the commerce information associated with invasive species interceptions at points of entry or along invasion pathways. Those trade data might also eventually be used to "make the polluter pay" for invasive species impacts (Jenkins 2002; Knowler and Barbier 2005). Resource managers recognize the risk that alreadyintroduced non-native species may be collected and intentionally spread to new locations for harvest (e.g., sport/food) (Hernández et al. 2018) or beautification (especially ornamental plants) (Blaustein 2001; Keil and Hickman 2014; Linz et al. 2007). Information system managers may also have limited data-sharing capacities due to the (a) various security restrictions that can provide political and technical barriers to data movement, and (b) lack of sufficient policy and personnel support, especially when sharing data is perceived to be beyond the core mission of a particular initiative.

Data quality and definition. Invasive species information systems and their outputs are only as good as the data contributed to them. The time and expense required to ensure that data are of high quality can be substantial and are notoriously difficult to secure institutionally. Being able to authoritatively define the applicability of data (fitness for use) is one aspect of ensuring data quality (Anderson et al. 2016; McGeoch 
et al. 2016). Because definitions of non-native species and invasive species vary, particularly with regard to the applicable scale of the definitions (e.g., ecosystem vs. political jurisdiction) (Richardson et al. 2000; Colautti and MacIsacc 2004; Beck et al. 2008; Simpson and Eyler 2018), data definition, valuation, and comparison can be difficult to achieve even within a single information system that serves as a repository of data from multiple sources.

For the purposes of this paper, unless otherwise distinguished to make a specific point, we use the term "non-native species data" to include the subset of data that could be defined as "invasive species." However, in keeping with programmatic norms, we refer to "invasive species information systems" and a "national invasive species information framework" as inclusive of all non-native species data, not just data backed by analyses of harm.

Information system cost and sustainability. The startup and maintenance costs of any given system need to be considered in the context of returns on investment over the long-term and across the scale of influence. Although an information system costbenefit analysis is beyond the scope of this paper, we emphasize the need for institutional recognition and commitment to information systems as their value increases over time. Due to financial and institutional limitations, there is a long history of biodiversity information system collapse, including for information systems focused on invasive species. This collapse includes total information system shutdown [e.g., the Invasive Species Information Node of the National Biological Information Infrastructure (Huber 2012)] and failure to update and/or quality control data over time even if the system still exists in name ["information system languish," e.g., the Global Invasive Species Information Network and the Invasive Plant Atlas of the MidSouth (Gore and Hossler 2006)]. Many of the databases relevant to invasive species management identified by Ridgway et al. (1999) no longer exist or have been inadequately maintained over the last two decades.

Information system independence and access. Biodiversity information systems are developed for many purposes by government agencies, non-governmental organizations, academic institutions, the private sector, and individuals. In many cases, the systems were not developed with the explicit intent of making the data publicly accessible or sharable among information systems and for more synthetic and overarching monitoring and analysis (e.g., Cooperative Agricultural Pest Surveys at https://napis.ceris. purdue.edu/home, Accessed 26 September 2019; Centre for Agriculture and Bioscience International's [CABI's] Crop Protection Compendium at https:// www.cabi.org/cpc, Accessed 26 September 2019). Although the quantity and quality of non-native species data have been improving over time, the information systems containing the data have often remained difficult to access and integrate (Groom et al. 2015; Western Governors' Association 2018).

Focus on environmental professionals. Traditionally, biodiversity information systems have housed data collected by environmental professionals. While this reflects the valid need to ensure that data are accurate and thus reliable for decision-making, it has also limited the scale of information input and information system support by a contributing public. Citizen scientists have demonstrated a strong will and capacity to contribute valuable biodiversity information (Amano et al. 2016; Chandler et al. 2016, 2017).

Because of the wide range of information needed to enable a national EDRR program (Table 1 and further discussed below), efforts must be focused on building a comprehensive national invasive species information framework (sometimes termed "cyberinfrastructure"; Graham et al. 2008). A national EDRR program thus depends on the capacity of the federal government and other information collectors and providers to overcome these basic biodiversity information system challenges. Progress is being made in this regard. For example, information systems are being developed at national and regional scales that focus on non-native species data (e.g., Western Governors' Association 2018), and pre-existing biodiversity information systems are being adapted to enable the uptake, sharing, and analysis of non-native species data (e.g., Simpson et al. 2009; Schimel et al. 2011). In a few cases, the provisioning of these non-native species data is undertaken with the stated intent of serving EDRR applications (e.g., Bargeron and Moorhead 2007; Lombard and Boettner 2014; Fuller and Neilson 2015).

Analytical tools are now widely available to make it more time- and cost-efficient to provide quality control of data (Vandepitte et al. 2015). Increasingly, data collected by citizen scientists is recognized as of equal value to data collected by environmental 
Table 1 Information needed to support a national EDRR program

\begin{tabular}{|c|c|c|c|c|}
\hline EDRR step & Information needs & $\begin{array}{l}\text { Information } \\
\text { sources }\end{array}$ & $\begin{array}{l}\text { Output } \\
\text { reporting }\end{array}$ & Comments \\
\hline $\begin{array}{l}\text { Target } \\
\text { analysis } \\
\text { (TA) }\end{array}$ & $\begin{array}{l}\text { What are the known/ } \\
\text { projected species } \\
\text { occurrence? } \\
\text { What are the } \\
\text { species/pathway } \\
\text { associations? } \\
\text { What are the species/ } \\
\text { ecosystem } \\
\text { associations? } \\
\text { What tools work to detect } \\
\text { which species under } \\
\text { what circumstances? }\end{array}$ & $\begin{array}{l}\text { Species distribution } \\
\text { mapping/modeling } \\
\text { Pathway } \\
\text { mapping/modeling } \\
\text { Niche } \\
\text { mapping/modeling } \\
\text { Biological profile } \\
\text { Best practices } \\
\text { reporting }\end{array}$ & $\begin{array}{l}\text { Internal agency } \\
\text { documents, if } \\
\text { reported at all }\end{array}$ & $\begin{array}{l}\text { Target analyses are not yet routinely enacted as a } \\
\text { component of the EDDR system }\end{array}$ \\
\hline Detection (D) & $\begin{array}{l}\text { What to search for? } \\
\text { Where to search? } \\
\text { When to search? } \\
\text { With what tool to search? }\end{array}$ & $\begin{array}{l}\text { Target analysis } \\
\text { Regulatory directive }\end{array}$ & $\begin{array}{l}\text { Programmatic } \\
\text { reports } \\
\text { Email or other } \\
\text { correspondence } \\
\text { Social media site }\end{array}$ & Detection may also be incidental \\
\hline $\begin{array}{l}\text { Identification } \\
\text { (ID) }\end{array}$ & $\begin{array}{l}\text { To what taxonomic level } \\
\text { is identification } \\
\text { necessary? } \\
\text { What is it? }\end{array}$ & $\begin{array}{l}\text { Taxonomic experts } \\
\text { Collections data } \\
\text { Genetic analysis } \\
\text { Identification guides } \\
\text { and apps } \\
\text { Internet search } \\
\text { Social media } \\
\text { crowdsourcing }\end{array}$ & $\begin{array}{l}\text { Species } \\
\text { occurrence } \\
\text { database } \\
\text { Vouchers } \\
\text { Programmatic } \\
\text { reports } \\
\text { Email or other } \\
\text { correspondence } \\
\text { Social media site }\end{array}$ & $\begin{array}{l}\text { Ideally, once authoritatively identified, incident } \\
\text { information is rapidly provided to a relevant open } \\
\text { source database }\end{array}$ \\
\hline $\begin{array}{l}\text { Reporting } \\
\text { (R) }\end{array}$ & $\begin{array}{l}\text { To whom does the } \\
\text { information need to be } \\
\text { reported? } \\
\text { How does the information } \\
\text { need to be reported? }\end{array}$ & $\begin{array}{l}\text { Regulatory } \\
\text { requirements } \\
\text { Policy guidelines } \\
\text { Incident response } \\
\text { plan } \\
\text { Internet search } \\
\text { Social media } \\
\text { crowdsourcing }\end{array}$ & $\begin{array}{l}\text { Standardized } \\
\text { alerts (internal } \\
\text { and/or public) } \\
\text { Email or other } \\
\text { correspondence } \\
\text { Social media } \\
\text { Publications } \\
\text { (professional } \\
\text { and popular } \\
\text { press) }\end{array}$ & $\begin{array}{l}\text { Ideally, reporting process pre-established in incident } \\
\text { response plan/policy guidance } \\
\text { Currently, reporting is likely to be chaotic and may } \\
\text { not reach the most appropriate person }\end{array}$ \\
\hline $\begin{array}{l}\text { Risk } \\
\text { Screening } \\
\text { (RS) }\end{array}$ & $\begin{array}{l}\text { What is it? } \\
\text { What are its potential } \\
\text { impacts under what } \\
\text { circumstances? }\end{array}$ & $\begin{array}{l}\text { Authoritative } \\
\text { identifier } \\
\text { Biological profile } \\
\text { Impact assessments }\end{array}$ & $\begin{array}{l}\text { Internal program } \\
\text { reports } \\
\text { Program } \\
\text { websites }\end{array}$ & $\begin{array}{l}\text { Results may indicate that a more in-depth risk } \\
\text { analysis is warranted } \\
\text { Ideally, would be reported in risk screening report } \\
\text { clearinghouse }\end{array}$ \\
\hline $\begin{array}{l}\text { Feasibility } \\
\text { Screening } \\
\text { (FS) }\end{array}$ & $\begin{array}{l}\text { What is the response } \\
\text { goal? } \\
\text { What response measures } \\
\text { are authorized and by } \\
\text { whom? } \\
\text { What technical, } \\
\text { logistical, and financial } \\
\text { resources are needed? } \\
\text { What relevant resources } \\
\text { are available? }\end{array}$ & $\begin{array}{l}\text { Regulatory review } \\
\text { Programmatic } \\
\text { review } \\
\text { Incident response } \\
\text { plan }\end{array}$ & $\begin{array}{l}\text { Internal program } \\
\text { reports }\end{array}$ & $\begin{array}{l}\text { Often, the costs of "doing nothing" can be higher } \\
\text { than the costs of attempting containment, } \\
\text { conducting research, and monitoring effectiveness } \\
\text { of EDRR }\end{array}$ \\
\hline
\end{tabular}


Table 1 continued

\begin{tabular}{|c|c|c|c|c|}
\hline EDRR step & Information needs & $\begin{array}{l}\text { Information } \\
\text { sources }\end{array}$ & Output reporting & Comments \\
\hline $\begin{array}{l}\text { Response } \\
\text { measures } \\
(\mathrm{RM})\end{array}$ & $\begin{array}{l}\text { Who is in charge? } \\
\text { Who is taking what action? } \\
\text { What is to be done? } \\
\text { How can it be done as effectively } \\
\text { and cost-efficiently as possible? } \\
\text { How well did it work? }\end{array}$ & $\begin{array}{l}\text { Regulatory } \\
\text { requirements } \\
\text { Best practice } \\
\text { guidelines and } \\
\text { policies } \\
\text { Incident response } \\
\text { plan } \\
\text { Context-specific } \\
\text { maps, models }\end{array}$ & $\begin{array}{l}\text { Institutional (per } \\
\text { regulatory } \\
\text { requirements) } \\
\text { Public (websites, } \\
\text { social media, etc.) }\end{array}$ & $\begin{array}{l}\text { Ideally, would be reported in } \\
\text { standardized database of response } \\
\text { measures }\end{array}$ \\
\hline
\end{tabular}

professionals and is thus being contributed into biodiversity information systems at various scales (Delaney et al. 2008). The popularity of citizen science initiatives is now driving the development of biodiversity identification and data collection apps to be employed on mobile phones (Martinez et al. 2019, this issue).

Open access and inter-operable information systems have become a cultural standard in the information management community writ large (Mauthner and Parry 2013), including among those working in the environmental field (Reichman et al. 2011). The NISC Secretariat recently released guidelines for invasive species information standardization and sharing to facilitate this process (Wallace et al. 2019, this issue).

Recommendations for developing an effective invasive species information framework have been made previously for national, regional, and global scales of application (Ricciardi et al. 2000; Federal Interagency Committee for the Management of Noxious and Exotic Weeds 2003; Fornwall and Loope 2004; Graham et al. 2008; Magarey et al. 2009; Helf 2011). Building on this previous body of work and consistent with the framework in Reaser et al. (2019a, this issue), we provide in Table 1 our perspective on the components required of an invasive species information framework intended to serve a national EDRR program. The following constitute the core operational principles for an invasive species information framework supporting EDRR:

(a) Adoption of standards, formats, and protocols that enable the interoperability of relevant information systems (Wallace et al. 2018, 2019, this issue); (b) Ability to handle increasingly large data sets (i.e., big data);

(c) Inclusion of data (ideally, authoritatively verified) on non-native species occurrence within the US according to species, point locality, and date of observation;

(d) Ability to distribute alerts of non-species occurrence (ideally, authoritatively verified) to those responsible for response needs assessment;

(e) Ability to notify data users when data corrections are made;

(f) Inclusion or link to data on the biological characteristics, documented impacts, and response measures for the non-native species globally;

(g) Capacity for data to be readily transferred into high-performance analytical and decision support tools that, at a minimum, enable target analyses (Morisette et al. 2019, this issue), risk screening (Meyers et al. 2019, this issue), costbenefit analyses of potential response measures and response prioritization (feasibility screening), and response planning; and.

(h) Cataloging of information products (ideally, standardized) resulting from data analyses mentioned in points $\mathrm{c}-\mathrm{f}$ (i.e., an open-access information product clearinghouse), including public-friendly species identification guides and watch lists (Reaser et al. 2019b, this issue).

The benefits of building a national invasive species information framework extend well beyond the direct application to invasive species prevention, eradication, and control. For example, resource managers could use occurrence data for highly flammable 
invasive grasses along with other relevant information to project fire risk (Pilliod et al. 2017), and infrastructure managers could use data on the occurrence of burrowing invasive species (such as non-native termites) to identify structures that may be at high risk of failure, especially during extreme weather events (Invasive Species Advisory Committee 2016). The cost savings to the public and the private sector from just these two additional applications could be in the billions of dollars annually.

\section{US Government policy}

The US federal government has responsibilities for information management at every stage in the EDRR process (Figure 1 in Reaser et al. 2019a, this issue; Table 1); agencies collect, manage, and share information, and they provide funding for non-federal information management activities that meet federal needs. Although specific visions have varied through time, the need for a strong federal invasive species information infrastructure (a key component of a national framework) has been recognized for at least two decades (Reaser et al. 2019a, this issue). For example, the Davis Declaration, which emerged out of a 2001 workshop held by the US Geological Survey (USGS) and the Global Invasive Species Programme in Davis, California, recognized the need for governments to have access to the information services and tools necessary for invasive species prevention, eradication, and control. It also acknowledged that invasive species information services were proliferating, but not being sufficiently coordinated. The authors of the Declaration noted a need to efficiently address overlapping and/or duplicative efforts and to minimize major gaps in coverage for some taxonomic groups and regions of the world. Among other things, the Davis workshop participants called for greater support for information system coordination, informatics tool development, and capacity building for information services (Fell 2001; Davis Declaration 2001).

Two decades later, it is difficult to quantify progress made by the US federal agencies in responding to the Davis Declaration and similar calls to action. Some of the shortcomings may be in keeping with the information management challenges outlined at the beginning of this paper: large focus on native species data (Simpson 1964); restrictions on data sharing (Ruhl
1998; Lueck and Michael 2003); and data fitness for use (Anderson et al. 2016; McGeoch et al. 2016). Others are due to the routine changes in federal policy priorities associated with administration turnover, such as the discontinuance of the US Invasive Species Early Detection Rapid Assessment and Response National Framework with the shutdown of the National Biological Information Infrastructure (Huber 2012). Fundamentally, the problem may reflect a general lack of recognition of the value of biological data and the returns on investment (economically, politically, and otherwise) that come from access to and analysis of reliable biodiversity information (Juutinen 2008; Laurila-Pant et al. 2015). This is a long-standing problem worldwide (Heywood 1995, Lindenmayer et al. 2012). The most relevant highlevel directives for federal invasive species information system advancement in the US are outlined below.

In 1999, Executive Order 13112 charged NISC with establishing a coordinated, up-to-date informationsharing system that emphasized the use of the internet for documenting, evaluating, and monitoring impacts from invasive species on the economy, the environment, and human and animal health (Executive Office of the President 1999). Acknowledging that relevant databases already existed for various purposes and that their current structures did not make for ease of information sharing (Ridgway et al. 1999), the first National Invasive Species Management Plan (NISC 2001) devoted a section to priority actions for advancing federal invasive species information management. Although the US Department of Agriculture (USDA) National Agriculture Library's National Invasive Species Information Center (https://www. invasivespeciesinfo.gov, Accessed 28 September 2019) was inspired by the Plan's intent and provides a gateway to relevant information resources, the envisioned information management outputs of the Plan remain largely unachieved. Specifically, the Plan's item 50, "an invasive species assessment and monitoring network comprised of on-the-ground managers of federal invasive species programs and appropriate technical specialists," has not been implemented. Item 51, "guidance for managing information concerning invasive species in aquatic and terrestrial environments... developed in consultation with [relevant agency bodies as listed], and other stakeholders, [to include] emerging technologies for information 
collection [and] lower-cost information tools for wide distribution" was not developed, and "standard protocols for information collection and sharing, including taxonomy, identification, inventory and mapping, monitoring, and assessments of invasive species populations" were developed by the non-governmental North American Weed Management Association in 2002, but only for mapping weeds (North American Invasive Species Management Association 2019). The Plan's item 53, a North American invasive species compendium, was not completed until 2012 and is global in scope (CABI 2019). To the authors' knowledge, the Plan's item 54, a comprehensive "locator for occurrences of invasive species in the United States within each county" has not been attempted.

The 2008-2012 National Invasive Species Management Plan (NISC 2008) included a section focused on enhancing data standards and quality to improve access and ability to search across databases and federal data sources. The majority of the action items were either a continuance of the actions identified in the previous plan (e.g., develop the Invasive Species Compendium), or tasks involving expansion of existing information systems (e.g., the PLANTS database [Natural Resources Conservation Service 2019] and NISbase, a database integrator now abandoned) and greater engagement in multi-national invasive species information initiatives (e.g., the Global Invasive Species Information Network, now largely abandoned for lack of funding). Much of this work, such as a plant pathogens database and an invasive species pathways database, also remains to be done.

The 2016-2018 NISC Management Plan (NISC 2016) included two action items intended to advance federal invasive species information management. The first was to establish guidance for data management standards, formats, and protocols. The output is included in this Special Issue (Wallace et al. 2019, this issue). As a follow-on to recommendations made in an interagency document broadly addressing federal EDRR capacities (US Department of the Interior 2016), the second priority action called for an assessment of "relevant federal information systems to provide the data and other information necessary for risk analyses/horizon scanning, rapid specimen identification, and rapid response planning" in the context of a national EDRR program. Our paper is one of three assessment outputs (see also Wallace et al. 2018 and Wallace et al. 2019, this issue).
Most recently, Executive Order 13751 (Executive Office of the President 2016) directed federal agencies to (a) develop, share, and utilize similar metrics and standards, methodologies, and databases and, where relevant, platforms for monitoring invasive species; and (b) facilitate the interoperability of information systems, open data, data analytics, predictive modeling, and data reporting necessary to inform timely, science-based decision-making. Collectively, the Council was directed to advance national incident response, data collection, and rapid reporting capacities that build on existing frameworks and programs and strengthen early detection of and rapid response to invasive species, including those that are vectors, reservoirs, or causative agents of disease.

In the remainder of this paper, we summarize the current capacities and needs for securing the federal information infrastructure, as a component of a national invasive species information framework, to support a national EDRR program. Although the directive and review are federally focused, we underscore the need for federal information systems to make data publicly available and to be able to interface with non-federal information systems domestically and internationally (particularly those of neighboring countries and trade partners). States have also recognized this need for data sharing, aggregation, and integration (Bois et al. 2011; Western Governors' Association 2018).

\section{Review of federal capacities}

In response to the aforementioned 2016-2018 NISC Management Plan directive, the NISC Secretariat invited the sixteen US federal bodies represented by Council leadership (https://www.doi.gov/ invasivespecies/about-nisc, accessed 28 September 2019) to respond to a survey (Reaser et al. 2019a, Appendix S1, this issue). Reaser et al. (2019a, this issue) provide an overview of the summary process and general outputs. The results of the information management component have been summarized by Wallace et al. (2018). In general, their report echoes previous findings (e.g., Ridgway et al. 1999; Bruno et al. 2001; Davis Declaration 2001), indicating that the US government lacks a coordinated invasive species information infrastructure at all levels (interdepartmental, department/agency, bureau, and even 
among sites within the same bureau); agencies have not yet cataloged information systems relevant to invasive species EDRR nor strategically assessed how their existing information systems could be improved to support EDRR; and biodiversity data collection among and within agencies is driven by multiple, dynamic factors (e.g., grant availability and project goals) that lead to inconsistent data collection (scope and frequency), highly variable data management (esp. data fields and frequency of updating), poor data and database standardization, and challenges with information system sustainability.

Federal agencies responding to the survey generally recognize a need for more consistent funding, sitespecific data on non-native presence (occurrence), absence (lack of detection), and documented impacts (especially economic impacts) by species in a locality. There is also a growing need for expanded information system functionality (e.g., ability to send or broadcast alerts of recent occurrences) and interoperability (i.e., sharing data into a limited number of data integrators allowing for more extensive data analyses). The survey also revealed a co-dependency between federal and non-federal information systems. Federal agencies rely heavily on generally more taxonomically or geographically focused non-federal information systems for data needed to advance key components of an EDRR system (e.g., occurrence, species identification, risk screening, response measure options), while many non-federal information systems rely on federal funding, endorsement, data input, and/or analytical support.

Three limitations should also be considered with regard to the findings of Wallace et al. (2018): (1) not all agencies responded (some do not host relevant information systems), (2) the depth of response varied widely among agencies, and (3) agencies may have information systems that are relevant to EDRR but not identified as such by the agency because the information system was developed with different goals in mind.

While gaps in agency responses exist, the review by Wallace et al. (2018) does provide a coarse-scale picture of how non-native species data are collected and used by various federal agencies. The responses from these agencies also express common challenges to information system capacity and substantial needs for improving the capacity of relevant information systems. The responses further indicate that federal government approaches to information management are unique to each agency. For example, some agencies are more engaged in cross-agency information sharing and/or working with non-federal partnerships than others. These findings suggest that any effort to build a multi-agency information framework to serve EDRR nationwide will need to carefully consider the differences in agency culture and how to foster a unified mission.

To garner a more comprehensive understanding of the information resources that federal agencies are using to enact EDRR and the remaining needs for building a comprehensive federal information infrastructure, we expanded on Wallace et al. (2018) by augmenting their findings through a five-pronged approach: (1) reviewing the survey results for findings not previously reported but of particular importance in the context of this paper, (2) adding information from previous invasive species information system assessments (Ridgway et al. 1999; Bruno et al. 2001), (3) including current programmatic information available online, (4) summarizing discussions with federal information system managers, and (5) including the expertise of the authors (all have experience establishing, managing, or routinely using federal invasive species information systems). The results of this effort have been published by Simpson et al. (2019) as a supplement to this paper.

Key issues not previously raised by Wallace et al. 2018 include:

(a) The definitions agencies use for non-native and invasive species affect what data are collected, how they are collected, and how they are reported. Relevant terms (e.g., quarantine pest, injurious wildlife) are frequently established in laws and policies without regard to the implications for data collection and analysis (BurgosRodríguez and Burgiel 2019a, this issue).

(b) Federal agencies are not consistently using the Integrated Taxonomic Information System (ITIS) Taxonomic Serial Numbers (TSNs) to ensure the consistency of scientific names, which has implications for the searchability and analysis of species occurrence data. The National Park Service (2019), for example, uses two additional taxonomic systems: NPSpecies Semi-permanent Names (Taxonomy records added by the NPSpecies system owner), and 
NPSpecies Temporary Names (Taxonomy records added by the NPSpecies user community). USDA's Agricultural Research Service (2019) has its own cadre of taxonomic experts with names that do not always appear in ITIS.

(c) Among the information systems used by federal agencies and as noted in Simpson et al. 2019, there are substantial differences in the timeframe in which species occurrence data are uploaded into publicly available information systems, ranging from immediate entry to a year or more. For EDRR applications, data need to be rapidly reported for authoritative identification and responsive decision-making (Simpson et al. 2009).

(d) Accessibility to data on non-native species intercepted at points of entry by APHIS and the Department of Homeland Security (which is not openly shared, National Agricultural Pest Information System 2019) could substantially increase the preparedness and response capacity of land and pathway (e.g., transportation) management agencies such as the Department of Transportation's Federal Highways Administration.

(e) Non-governmental information platforms, particularly those accessed through smartphones, are rapidly becoming standard operational tools for federal agencies (Wallace et al. 2016). However, the databases to which these data are contributed may not be interoperable with the federal databases used to analyze regional or national patterns and trends. This means that data collected by federal agencies may not be readily available in the federal invasive species information EDRR infrastructure (e.g., iNaturalist and eBird are contributed to the Biodiversity Information Service Our Nation [BISON] information system but not rapidly enough to support EDRR).

(f) Information systems that include non-native species data as a subset of all biodiversity data (e.g., BISON at USGS and the USDA Plant List of Attributes, Names, Taxonomy, and Symbols [PLANTS] in the federal system, and iNaturalist and eBird in the private sector) are not being fully leveraged by federal agencies for their non-native species occurrences. For example, some federal survey responses (described in
Wallace et al. 2018) suggest that agencies may be unaware of these large information resources and/or their potential application to EDRR.

(g) In general, non-native species data are not being sufficiently managed to enable a wide-range of analytical applications. For example, the data contained in many information systems are not processed and/or delivered in a manner that makes them readily useable for species distribution modeling, especially for projecting future patterns and trends (Elith et al. 2006). Museums that collect data important to taxonomic relationships may only secondarily provide the exact location of the species (which can be used for distribution modeling). Issues regarding "fitness for use" are not uncommon because data are often collected for reasons narrower than the possible applications that emerge through time (Guillera-Arroita et al. 2015). Cost efficiencies may improve when data are retroactively "made fit" in lieu of new data collection (Frank 1998), but this depends on the type of data and purpose of application.

Our review enabled us to create the first catalog of databases and information tools (Simpson et al. 2019) that federal agencies are using to enact EDRR. In total, 44 databases and 51 information tools were identified (e.g., apps). It should be noted that the distinction between database and information tool may not have been readily apparent or warranted. Thus, the same information system may be included in both catalogs, and some information system managers may have different opinions with regard to placement in the catalog. Also, our compilation represents a snapshot in time. Nevertheless, static versions of these catalogs have been published, and it is our intention to make periodic updates to this catalog available via USGS's ScienceBase online system. The dynamic versions will serve as living resources for federal agencies and their partners, but the current version is frozen for archival purposes. These databases and tools are the foundation on which a comprehensive federal invasive species information infrastructure can be built and contribute to a national EDRR program.

By creating the catalog, identifying the database or tool attributes, and reviewing the outstanding information system needs identified by the federal agencies, we were able to summarize the status of federal 
information system capacities in accordance with each of the EDRR components identified in Table 1. This status is summarized in Table 2. Information gaps are apparent for each EDRR component, but particularly remarkable for supporting target analysis, sharing the outputs of target analyses, performing risk and feasibility screening, and implementing response measures. This lack of capacity greatly undermines the ability of government agencies to institutionalize and enact effective incident command structures (Burgiel 2019, this issue).

\section{Summary of principles and needs identified}

Developing the national invasive species information framework to support a national EDRR program is a formidable task. Based on our assessment of current capacity and lessons learned from previous efforts (Federal Interagency Committee for the Management of Noxious and Exotic Weeds 2003; US Department of the Interior 2016), success will largely depend on the ability of government agencies and their partners to agree to a common vision and leadership mandates, secure vital information systems over the long term, motivate data reporting and sharing, improve current information system capacities, and invest in-or otherwise promote-the development of associated analytical tools. Adherence to the following operational principles will facilitate information framework development.

No single information system can do it all. A coordinated framework of interoperable information systems, federal and non-federal, is required (Graham et al. 2008).

Think and act openly. Open-access information systems are now a "best practice" for information management. The federal government has established open-access policies (https://www2.usgs.gov/quality_ integrity/open_access, Accessed 26 November 2018). However, there is still a need to mobilize non-public federal data into publicly accessible information systems. This is particularly true of species occurrence (intercept) data collected at points of entry (National Agricultural Pest Information System 2019).

Information systems not initially designed for EDRR can support EDRR. Well-established biodiversity databases can help advance an invasive species information framework by encouraging the collection and reporting of non-native species data. For example, the US Geological Survey's BISON database (https:// bison.usgs.gov) recently expanded its services to support identification and searchability for the more than 14 million non-native species data points that it already had (Simpson and Eyler 2018).

Existing information systems represent substantial investments in time and money. In most cases, it will be more cost-effective to improve existing information systems rather than create new ones. If new information systems are developed, they should be designed according to established guidelines for inter-operability (e.g., Wallace et al. 2019, this issue).

Many of the following identified actions build on previous assessments of federal invasive species information needs (e.g., Ridgway et al. 1999; Bruno et al. 2001) and summarize what we see as a proactive way forward.

Establish common vision and goals. An invasive species information framework needs to be guided by strategic vision and long-term goals that advance the mission of federal agencies and their partners to prevent, eradicate, and control invasive species in a well-coordinated, effective, and cost-efficient manner. The vision must be sufficiently compelling to motivate agencies to overcome long-standing challenges to biodiversity information management. The goals need to (a) be achievable within realistic resource capacities and timeframes and (b) allow progress and returns on investment to be measured (Lindenmayer et al. 2012).

Designate leadership roles and responsibilities. A government-wide invasive species data management policy can be used to establish data custodial roles and management responsibilities from agency to programmatic levels, address relevant legal and policy issues (including privacy and security), and institutionalize invasive species information management guidelines (Wallace et al. 2019, this issue). While the policy should be authoritative and specific enough for agencies to discern their obligations, it will need to be sufficiently flexible to account for unanticipated needs and emerging opportunities (Epanchin-Niell et al. 2018).

Identify and sustain vital information systems. The invasive species information framework needs to clearly identify the federal information systems that are vital to the operation of a national EDDR program (Simpson et al. 2019), assess their relationships (e.g., for duplicative or integrative functions), and include a 
Table 2 Gaps in information by EDRR component

\begin{tabular}{ll}
\hline EDRR framework component (See & $\begin{array}{l}\text { Gaps identified through the federal survey information (Wallace et al. 2018), agency staff } \\
\text { interviews, reviews of information available through federal websites and reports, peer- } \\
\text { Reaser et al. 2019a) }\end{array}$ \\
& reviewed literature, and the authors' collective expertise (Simpson et al. 2019)
\end{tabular}

Target analysis (TA)

There are defined federal processes and related information on pre-border risk screening and there are information systems related to sampling at ports of entry, though these are not public and are concentrated on agricultural systems. There is a lack of any federally coordinated system for sampling along other points of entry and recipient ecosystems, or for coordinating analyses and tools nationally or across taxonomic groups

Detection (D)

Federal systems are available for recording and mapping occurrences (e.g., USGS' Biodiversity Information Serving Our Nation and Nonindigenous Aquatic Species databases), and the private sector is cooperating (e.g., iMapInvasives \& EDDMaps). However, a lack of data mobilization from non-federal, hidden systems (especially in state and local governments) presents a challenge. Rapid deployment of new data is also significantly resource limited

Identification (ID)

Several systems supporting detection ensure some level of checking to ensure proper identification. However, metadata on this confirmation is often lacking. There are existing systems for standardizing names (e.g., the Integrated Taxonomic Information System) and tools (e.g., artificial intelligence applied to photos and DNA barcoding) that can support identification, but there is a serious shortage of expert taxonomists for confirmation and vetting

Reporting (RP)

There is general information available (like who the county weed manager is). There are also systems that provide alerts related to species of concern and pre-defined geographies. However, there are no public information systems that provide information management pertaining to properly identified occurrence observations being reported to a responsible party in a timely manner. This is particularly concerning for occurrences on public lands where federal agencies are responsible for action

Risk screening (RS)

There are some open-access coordinated federal information systems that tracks risk screening but only from one or a few components; thus lacking the holistic perspective. These systems are species and region-specific

Feasibility screening (FS)

There does not appear to be any open-access coordinated federal information that tracks feasibility screening at the granularity of individual events for any taxa or region

Response measures (RM)

No national system existing to report or query at the level of individual or specific response measures. Examples exist where treatments can be noted (EDDMapS) or information on the occurrence status is maintained (USGS' Nonindiginous Aquatic Species database)

plan for sustaining these systems over the long-term. Partnerships with industries, especially those trading in live commodities or their parts, could lead to costsharing for the collection of invasive species data that are of clear benefit to public and private sectors (Pattberg and Widerberg 2016). Collaborative agreements must clarify respective partner roles, open access to data, and data ownership.

Resolve sensitive data issues. As mentioned previously, one of the greatest challenges for administering an invasive species information framework will be motivating and enabling the sharing of sensitive data. Ideally, information systems associated with trade data (e.g., the US Fish and Wildlife Service Law Enforcement Management Information System
[LEMIS]) should be designed to allow for sharing species occurrence data (absent links to proprietary information) rather than being entirely restricted (Ridgway et al. 1999). In addition to the adoption of an overarching data policy (discussed above) and information management guidelines (Wallace et al. 2019, this issue), there is a need for data-sharing agreements (especially between data providers and data integrators; Fornwall and Loope 2004) that clearly state goals and procedures for data handling. Ultimately, the system may require a process for deresolving and providing limited access to particularly sensitive data (Jarnevich et al. 2007) while ensuring data are still useful and correct. For example, data obfuscation methods in the US Forest Inventory 
Analysis program (Bechtold and Patterson 2005) can have significant consequences for re-use (Coulston and Reams 2004).

Launch a data mobilization campaign. The cultural challenge of data sharing at individual and institutional levels will need to be overcome (Simpson et al. 2006), because partnerships with non-federal data providers will be vital to enacting a national invasive species information framework (Ridgway et al. 1999). A national non-native species data mobilization campaign is needed to (1) create a shared identity for those contributing to the operation of the national invasive species information framework, (2) focus information acquisition and sharing for filling data gaps in taxonomic and locality coverage, (3) articulate clearly the institutional and individual benefits of data reporting and sharing, and (4) motivate additional resource allocations. The campaign could emphasize the ability of a national invasive species information framework to leverage limited resources (time, money, personnel) with minimal additional cost and effort (Crall et al. 2006) by, among other things, enabling the following:

(a) Mining of data for which there has already been financial investment (including databases, published literature, museum collections, gene banks);

(b) Ongoing improvement of non-native species lists at various scales to assist detection targeting and encourage reporting (Crosier and Stohlgren 2004);

(c) Combining occurrence data with various models to identify data needs and improve forecasting and projection models from spatial and temporal perspectives (Crosier and Stohlgren 2004); and.

(d) Establishing and sharing EDRR information tools such as watch lists (Rejmánek and Pitcairn 2002; Reaser et al. 2019b, this issue), identification guides (Silvertown 2009), and reporting apps (Graham et al. 2011) that help prioritize and target resources.

Improve information system capacities. Wallace et al. (2018) indicate that the federal information systems key to building a national invasive species information framework (and thus a national EDRR program) need further support. Nearly all the responding agencies expressed a need for increased funding, additional data (type and volume), improved functionality to serve EDRR needs, and improved interoperability for data sharing. For example, in the agency survey described by Wallace et al. (2018) the National Park Service said that their National Invasive Species Information Management System (NISIMS) would need to be updated more frequently and include an alert system to be particularly useful for EDRR applications.

Foster analytical tools. A wide range of informatics tools are needed to support a national EDRR program. These include specialized data search tools for distinguishing what is invasive in what context and with what consequences (ideally, distinguishing invasive from simply non-native at the ecosystem level); mapping tools for illustrating species occurrence information, ideally in association with relevant ecological, geographic, and jurisdictional information (Wallace et al. 2016); apps for assisting in species identification (Graham et al. 2011; Lyal and Miller 2019, this issue; Martinez et al. (2019), this issue); and decision support tools for (a) standardized risk analyses (Meyers et al. 2019, this issue), (b) horizon scanning and other relevant spatio-temporal modeling (Sutherland and Woodruff 2009; Morisette et al. 2019, this issue), and (c) evaluation of the effectiveness, costs, and risks of various response measures in particular contexts (Ridgway et al. 1999). To successfully foster these analytical tools, broad partnerships are needed, such as the new Invader Detectives initiative (Frey 2018) being piloted by the Capital Area Partnership for Regional Invasive Species Management (PRISM; https://www.inaturalist.org/guides/ 5799, Accessed 26 November 2018) and the Wild Spotter campaign that promotes invasive species reporting and response in natural areas in the United States (https://wildspotter.org, Accessed 27 November 2018).

Establish report clearinghouses. Respondents to the federal information survey repeatedly called for open-access, searchable clearinghouses for the reports arising from target analyses (Morisette et al. 2019, this issue), risk evaluations (Meyers et al. 2019, this issue), feasibility screening, and response measures. The Great Lakes Aquatic Nonindigenous Species Information System (https://www.glerl.noaa.gov/glansis/ riskAssessment.html, Accessed 26 November 2018) supported by the National Oceanic and Atmospheric Information System and US Environmental Protection 
Agency is an example of a regional risk evaluation clearinghouse.

\section{Conclusion}

The challenges to envisioning and sustaining a national invasive species information framework are numerous and substantial. Perfection is an unrealistic ideal [e.g., all taxonomic groups and localities will not be served equally (Graham et al. 2008)] but making substantial advances in our capacity to enact EDRR is a realistic and necessary goal if we are to spare the nation the wide range of costly impacts of invasive species.

The federal component of a national invasive species information framework will become more feasible as (a) the inherent value of data is increasingly recognized by the public and private sectors, (b) there is an increase in the number of partnerships between the federal government and the private sector to support big data initiatives and associated analytical capacities, and (c) early and effective action for invasive species detection and removal, enabled by more reliable and integrated data, eventually reduces funding needs for invasive species control. There may also be opportunities to engage stakeholders impacted by invasive species who could benefit from investing in the information that would help protect their assets.

Acknowledgements This paper advances action 5.1.6 of the 2016-2018 NISC Management Plan. The authors are grateful to everyone who contributed to the federal agency surveys and supplemental inquires. The authors thank Catherine Jarnevich, Tom Stohlgren, Laura Meyerson, and Dan Simberloff for reviews that improved the manuscript. Jason Kirkey provided invaluable editorial assistance. Financial support for this project was provided through Service First funding to the NISC Secretariat. Any use of or reference to trade, firm, or product names is for descriptive purposes only and does not imply endorsement by the US Government. The views expressed in this publication do not necessarily represent the views of the US Government

Author Contributions The majority of Jamie K. Reaser's contributions to this manuscript occurred while she was Executive Director of NISC.

\section{Compliance with ethical standards}

Conflict of interest The authors declare that they have no conflict of interest.
Open Access This article is licensed under a Creative Commons Attribution 4.0 International License, which permits use, sharing, adaptation, distribution and reproduction in any medium or format, as long as you give appropriate credit to the original author(s) and the source, provide a link to the Creative Commons licence, and indicate if changes were made. The images or other third party material in this article are included in the article's Creative Commons licence, unless indicated otherwise in a credit line to the material. If material is not included in the article's Creative Commons licence and your intended use is not permitted by statutory regulation or exceeds the permitted use, you will need to obtain permission directly from the copyright holder. To view a copy of this licence, visit http://creativecommons.org/licenses/by/4.0/.

\section{References}

Agricultural Research Service (2019) Pest Control/Management and Systematics. https://www.ars.usda.gov/northeast-area/ docs/systematics-research/pest-controlmanagement-andsystematics/. Accessed 11 July 2019

Amano T, Lamming JDL, Sutherland WJ (2016) Spatial gaps in global biodiversity information and the role of citizen science. Bioscience 66:393-400

Anderson RP, Araújo M, Guisan A, Lobo JM, Martínez-Meyer E, Peterson AT, Soberón J (2016) Report of the task group on GBIF data fitness for use in distribution modelling. Global Biodiversity Information Facility. http://www.gbif. org/resource/82612. Accessed 5 July 2018

Bargeron CT, Moorhead DJ (2007) EDDMapS — early detection and distribution mapping system for the southeast exotic pest plant council. Wildland Weeds 10:4-8

Bechtold WA, Patterson P L (2005) The enhanced forest inventory and analysis program — national sampling design and estimation procedures. Gen Tech Rep SRS-80. US Department of Agriculture, Forest Service, Southern Research Station, Asheville, NC

Beck KG, Zimmerman K, Schardt JD, Stone J, Lukens RR et al (2008) Invasive species defined in a policy context: recommendations from the federal invasive species advisory committee. Invasive Plant Sci Manag 1:414-421

Blaustein RJ (2001) Kudzu's invasion into Southern United States life and culture. In: McNeely JA (ed) The great reshuffling: human dimensions of invasive species. World Conservation Union, Gland, Switzerland

Bois ST, Silander JA Jr, Mehrhoff LJ (2011) Invasive plant atlas of New England: the role of citizens in the science of invasive alien species detection. Bioscience 61(10):763-770

Bruno D, Hedberg R, Hiebert R, Lane EM, Olivarez J et al (eds) (2001) Western rangeland noxious weeds: collecting, sharing and using information. Charles Valentine Riley Memorial Foundation, Silver Spring

Burgiel SW (2019) The incident command system: a framework for rapid response to biological invasion. Biol Invasions. https://doi.org/10.1007/s10530-019-02150-2

Burgos-Rodríguez J, Burgiel SW (2019a) Federal legal authorities for the early detection of and rapid response to 
invasive species. Biol Invasions. https://doi.org/10.1007/ s10530-019-02148-w

Burgos-Rodríguez J, Burgiel SW (2019b) Federal legal authorities: guidance for application to the early detection of and rapid response to invasive species. Biol Invasions. https://doi.org/10.1007/s10530-019-02149-9

Centre for Agriculture and Bioscience International (2019) Invasive Species Compendium Overview. https://www. cabi.org/isc/overview. Accessed 11 July 2019

Chandler M, Rullman S, Cousins S, Esmail N, Begin E, Venicx G, Eisenberg C, Studer M (2016) Contributions to publications and management plans from 7 years of citizen science: use of a novel evaluation tool on Earthwatchsupported projects. Biol Conserv 208:163-173

Chandler M, See L, Copas K, Bonde AMZ, Lopez BC et al (2017) Contribution of citizen science towards international biodiversity monitoring. Biol Conserv 213:280-294

Colautti RI, MacIsacc HJ (2004) A neutral terminology to define 'invasive' species. Divers Distrib 10:135-141

Coulston JW, Reams GA (2004) The effect of blurred plot coordinates on interpolating forest biomass: a case study. In: Proceedings of the joint meeting of the 15th annual conference of the International Environmetrics Society and the 6th international symposium on spatial accuracy assessment in natural resources and environmental sciences. https://www.srs.fs.usda.gov/pubs/ja/ja_ coulston005.pdf. Accessed 15 Nov 2018

Crall AW, Meyerson LA, Stohlgren TJ, Jarnevish CS, Newman GJ, Graham J (2006) Show me the numbers: what data currently exist for non-native species in the USA? Front Ecol Environ 4:414-418

Crosier CS, Stohlgren TJ (2004) Improving biodiversity knowledge with data set synergy: a case study of nonnative plants in Colorado. Weed Technol 18:1441-1444

Davis Declaration (2001) Workshop on Development of Regional Invasive Alien Species Information Hubs, Including Requisite Taxonomic Services, in North America and Southern Africa, 14-15 February 2001, Davis, California. https://www.doi.gov/sites/doi.gov/files/ uploads/davis_declaration_on_invasive_species_2001. pdf. Accessed 15 Nov 2018

Delaney DG, Sperling CD, Adams CS, Leung B (2008) Marine invasive species: validation of citizen science and implications for national monitoring networks. Biol Invasions 10(1):117-128. https://doi.org/10.1007/s10530-007-91140

Elith J, Graham CH, Anderson RP, Dudík M, Ferrier S et al (2006) Novel methods improve prediction of species' distributions from occurrence data. Ecography 29(2):129-151

Epanchin-Niell RS, Boyd JW, Macauley MK, Scarlett L, Shapiro CD, Williams BK (2018) Integrating adaptive management and ecosystem services concepts to improve natural resource management: challenges and opportunities. US Geol Surv Circular. https://doi.org/10.3133/ cir1439

Executive Office of the President (1999) Executive Order 13112, 64 FR 6183-6186, February 8, 1999

Executive Office of the President (2016) Executive Order 13751, 81 FR 88609-88614, December 5, 2016
Federal Interagency Committee for the Management of Noxious and Exotic Weeds (2003) A national early detection and rapid response system for invasive plants in the United States: conceptual design. https://my.usgs.gov/confluence/ display/FICMNEW/Open+Reports?preview=/ 594641040/594643415/FICMNEW_EDRR_FINAL.pdf. Accessed 06 July 2018

Fell A (2001) Davis Declaration Calls for Action on Invasive Species. University News, UC Davis. https://www. ucdavis.edu/news/davis-declaration-calls-action-invasivespecies. Accessed 15 Nov 2018

Fornwall M, Loope L (2004) Toward a comprehensive information system to assist invasive species management in Hawaii and Pacific Islands. Weed Sci 52:854-856

Frank A (1998) Metamodels for data quality description. In: Goodchild M, Jeansoulin R (eds) Data quality in geographic information: from error to uncertainty. Editions Hermes, Paris. https://pdfs.semanticscholar.org/f346/ e5398af0abedd755c15509e7c03cad2a020c.pdf. Accessed 24 July 2019

Frey M (2018) Invader detectives: EDRR pilot project. Contractor's Report. National Invasive Species Council, Washington, DC

Fuller P, Neilson ME (2015) The US geological survey's nonindigenous aquatic species database: over thirty years of tracking introduced aquatic species in the United States (and counting). Manag Biol Invasions 6(2):159-170. https://doi.org/10.3391/mbi.2015.6.2.06

Gore W, Hossler D (2006) Why all the fuss about information systems? or Information systems as golden anchors in higher education. New Dir Higher Educ 136:7-20. https:// doi.org/10.1002/he.236

Graham J, Simpson A, Crall A, Jarnevich C, Newman G, Stohlgren TJ (2008) Vision of a cyberinfrastructure for nonnative, invasive species management. Bioscience 58:263-268

Graham EA, Henderson S, Schloss A (2011) Using mobile phones to engage citizen scientists in research. Eos 92(38):313-315. https://doi.org/10.1029/2011EO380002

Groom QJ, Desmet P, Vanderhoeven S, Adriaens T (2015) The importance of open data for invasive alien species research, policy and management. Manag Biol Invasions 6(2):119-125

Guillera-Arroita G, Lahoz-Monfort JJ, Elith J, Gordon A, Kujala $\mathrm{H}$ et al (2015) Is my species distribution model fit for purpose? Matching data and models to applications. Glob Ecol Biogeogr 24(3):276-292. https://doi.org/10.1111/ geb. 12268

Helf KL (2011) On the application of the cyberinfrastructure model for efficiently monitoring invasive exotic species. Parks Sci 27(3):29-33

Hernández FA, Parker BM, Pylant CL, Smyser TJ, Piaggio AJ et al (2018) Invasion ecology of wild pigs (Sus scrofa) in Florida, USA: the role of humans in the expansion and colonization of an invasive wild ungulate. Biol Invasions 20(7):1865-1880

Heywood VH (ed) (1995) The global biodiversity assessment. United Nations Environment Programme. Cambridge University Press, Cambridge

Huber R (2012) Termination of the National Biological Information Infrastructure. Stratigraphy.net Internals http:// 
stratigraphynet.blogspot.com/2012/01/termination-ofnational-biological.html. Accessed 10 July 2019

Invasive Species Advisory Committee (2016) Invasive species impacts on infrastructure. Invasive Species Advisory Committee, Washington, DC https://www.doi.gov/sites/ doi.gov/files/uploads/isac_infrastructure_white_paper.pdf. Accessed 9 July 2018

Jarnevich CS, Graham JJ, Newman GJ, Crall AW, Stohlgren TJ (2007) Balancing data sharing requirements for analyses with data sensitivity. Biol Invasions 9(5):597-599

Jenkins P (2002) Paying for protection from invasive species. Issues Sci Technol 19(2):67-72

Juutinen A (2008) Old-growth boreal forests: worth protecting for biodiversity? J For Econ 14(4):242-267

Keil KE, Hickman KR (2014) Mapping distribution in Oklahoma and raising awareness: purple loosestrife (Lythrum salicaria), multiflora rose (Rosa multiflora), and Japanese honeysuckle (Lonicera japonica). Oklahoma Native Plant Record 1:50-66. http://ojs.library.okstate.edu/osu/index. php/ONPR/article/view/2995/2691. Accessed 09 July 2018

Knowler D, Barbier E (2005) Importing exotic plants and the risk of invasion: are market-based instruments adequate? Ecol Econ 52(3):341-354

Laurila-Pant M, Lehikoinen A, Uusitaloc L, Venesjärvi R (2015) How to value biodiversity in environmental management? Ecol Indic 55:1-11

Lindenmayer DB, Gibbons P, Bourke M, Burgman M, Dickman $\mathrm{CR}$ et al (2012) Improving biodiversity monitoring. Aust Ecol 37(3):285-294. https://doi.org/10.1111/j.1442-9993. 2011.02314.x

Linz GM, Homan HJ, Gaulker SM, Penry LB, Bleier WJ (2007) European starlings: a review of an invasive species with far-reaching impacts. Manag Vertebr Invasive Species 24:378-386

Lombard K, Boettner C (2014) Early detection of new plant invaders in New England: your help is needed! Rhodora 116(967):356-358. https://doi.org/10.3119/14-03

Lueck D, Michael JA (2003) Preemptive habitat destruction under the Endangered Species Act. J Law Econ 46:27-60

Lyal CHC, Miller SE (2019) Capacity of United States federal government and its partners to rapidly and accurately report the identity (taxonomy) of non-native organisms intercepted in early detection programs. Biol Invasions. https://doi.org/10.1007/s10530-019-02147-x

Magarey RD, Colunga-Garcia M, Fieselmann DA (2009) Plant biosecurity in the United States: roles, responsibilities, and information needs. Bioscience 59:875-884

Martinez B, Reaser JK, Dehgan A, Zamft B, Baisch D, et al (2019) Technology innovation: advancing capacities for the early detection of and rapid response to invasive species. Biol Invasions. https://doi.org/10.1007/s10530-01902146-y

Mauthner NS, Parry O (2013) Open access digital data sharing: principles, policies and practices. Soc Epistemol 27:47-67

McGeoch M, Groom QJ, Pagad S, Petrosyan V, Wilson J, and Ruiz G (2016) Data fitness for use in research on alien and invasive species. Global Biodiversity Information Facility. https://www.gbif.org/document/82958/data-fitness-foruse-in-research-on-alien-and-invasive-species. Accessed 6 June 2018
Meyers NM, Reaser JK, Hoff MH (2019) Instituting a national early detection and rapid response program: needs for building federal risk screening capacity. Biol Invasions. https://doi.org/10.1007/s10530-019-02144-0

Morisette JT, Reaser JK, Cook GL, Irvine KM, Roy HE (2019) Right place. Right time. Right tool: guidance for using target analysis to increase the likelihood of invasive species detection. Biol Invasions. https://doi.org/10.1007/s10530019-02145-Z

National Agricultural Pest Information System (2019) National Agricultural Pest Information System. https://napis.ceris. purdue.edu/home. Accessed 11 July 2019

National Invasive Species Council (2001) Meeting the invasive species challenge: national invasive species management plan. Washington, DC. https://www.doi.gov/sites/doi.gov/ files/migrated/invasivespecies/upload/2001-InvasiveSpecies-National-Management-Plan.pdf. Accessed 09 July 2018

National Invasive Species Council (2008) 2008-2012 National invasive species management plan. Washington, DC. https://www.doi.gov/sites/doi.gov/files/migrated/ invasivespecies/upload/2008-2012-National-InvasiveSpecies-Management-Plan.pdf. Accessed 09 July 2018

National Invasive Species Council (2016) 2016-2018 Management Plan. Washington, DC. https://www.doi.gov/sites/ doi.gov/files/uploads/2016-2018-nisc-management-plan. pdf. Accessed 09 July 2018. Accessed 26 Sept 2019

National Park Service (2019) Integrated Resource Management Applications Portal. https://irma.nps.gov/content/help/ taxonomy/Glossary.aspx. Accessed 11 July 2019

Natural Resources Conservation Service (2019) The PLANTS Database. http://plants.usda.gov. Accessed 11 July 2019

North American Invasive Species Management Association (2019) Mapping Standards. https://www.naisma.org/ standards/mapping-standards-previous. Accessed 11 July 2019

Pattberg P, Widerberg O (2016) Transnational multistakeholder partnerships for sustainable development: conditions for success. Ambio 45(1):42-51. https://doi.org/10.1007/ s13280-015-0684-2

Pilliod D, Welty JL, Arkle AS (2017) Refining the cheatgrassfire cycle in the Great Basin: precipitation timing and fine fuel composition predict wildfire trends. Ecol Evol 7:8126-8151

Reaser JK, Burgiel SW, Kirkey J, Brantley KA, Veatch SD, Rodríguez-Burgos J (2019a) The early detection of and rapid response (EDRR) to invasive species: a conceptual framework and federal capacities assessment. Biol Invasions. https://doi.org/10.1007/s10530-019-02156-w

Reaser JK, Frey M, Meyers NM (2019b) Invasive species watch lists: guidance for development, communication, and application. Biol Invasions. https://doi.org/10.1007/ s10530-019-02176-6

Reichman OJ, Jones MB, Schildhauer MP (2011) Challenges and opportunities of open data in ecology. Science 331:703-705

Rejmánek M, Pitcairn MJ (2002) When is eradication of exotic pest plants a realistic goal? In: Veitch CR, Clout MN (eds) Turning the tide: the eradication of invasive species. Occasional Paper of the IUCN Species Survival Commission 27:249-253 https://portals.iucn.org/library/sites/ 
library/files/documents/SSC-OP-028.pdf\#page $=255$.

Accessed 09 July 2018

Ricciardi A, Steinger WWM, Mack RN, Simberloff D (2000) Toward a global information system for invasive species. Bioscience 50:239-244

Richardson DM, Pyšek P, Rejmánek M, Barbour MG, Panetta FD, West CJ (2000) Naturalization and invasion of alien plants: concepts and definitions. Divers Distrib 6:93-107

Ridgway RL, Gregg WP, Stinner RE, Brown AG (eds) (1999) Invasive species databases: proceedings of a workshop. Charles Valentine Riley Memorial Foundation, Silver Spring, MD

Ruhl JB (1998) How to kill endangered species, legally: the nuts and bolts of Endangered Species Act HCP permits for real estate development. Environ Law 5:345

Schimel D, Keller M, Berukoff S, Kao B, Loescher H, et al (2011) Science strategy: enabling continental-scale ecological forecasting. National Ecological Observing Network, Fort Collins, Colorado. https://www.neonscience. org/sites/default/files/basic-page-files/NEON_Strategy_ 2011u2_1.pdf. Accessed 9 July 2018

Silvertown J (2009) A new dawn for citizen science. Trends Ecol Evol 24(9):467-471. https://doi.org/10.1016/j.tree. 2009.03.017

Simpson GG (1964) Species density of North American recent mammals. Syst Zool 13(2):57-73

Simpson A, Eyler MC (2018) First comprehensive list of nonnative species established in three major regions of the United States: US Geological Survey Open-File Report 2018-1156. https://doi.org/10.3133/ofr20181156

Simpson A, Sellers E, Grosse A, Xie Y (2006) Essential elements of online information networks on invasive alien species. Biol Invasions 8:1579-1587

Simpson A, Jarnevich C, Madsen J, Westbrooks R, Fournier C et al (2009) Invasive species information networks: collaboration at multiple scales for prevention, early detection, and rapid response to invasive alien species. Biodiversity 10:5-19

Simpson A, Morisette JT, Fuller P, Reaser J, Guala GF (2019) Catalog of US federal early detection/rapid response invasive species databases and tools: US Geological Survey data release. https://doi.org/10.5066/p9cnvbyr
Sutherland WJ, Woodruff HJ (2009) The need for environmental horizon scanning. Trends Ecol Evol 24(10):523-527. https://doi.org/10.1016/j.tree.2009.04. 008

US Department of the Interior (2016) Safeguarding America's lands and waters from invasive species: a national framework for early detection and rapid response, Washington DC. https://www.doi.gov/sites/doi.gov/files/uploads/ national_edrr_framework_2016.pdf. Accessed 9 July 2018

Vandepitte L, Vanhoorne B, Decock W, Dekeyzer S, Verbeeck AT et al (2015) How Aphia-the platform behind several online and taxonomically oriented databases - can serve both the taxonomic community and the field of biodiversity informatics. J Mar Sci Eng 3(4):1448-1473. https://doi. org/10.3390/jmse3041448

Wallace RD, Bargeron CT, Moorhead DJ, LaForest JH (2016) IveGot1: Reporting and Tracking Invasive Species in Florida. Southeastern Naturalist 15(sp8). https://doi.org/ 10.1656/058.015.sp805

Wallace RD, Bargeron CT, Moorhead DJ, LaForest JH (2018) Information management relevant to invasive species early detection and rapid response programs. Contractor's Report. National Invasive Species Council, Washington, DC https://www.doi.gov/sites/doi.gov/files/uploads/ information_systems_edrr_5june2018.pdf. Accessed 15 Nov 2018

Wallace RD, Bargeron IV CT, Reaser JK (2019) Enabling decisions that make a difference: guidance for improving access to and analysis of invasive species information. Biol Invasions. https://doi.org/10.1007/s10530-019-02142-2

Western Governors' Association (2018) Western Governors' Association Invasive Species Data Management Workshop findings and recommendations. http://westgov.org/images/ editor/WGA_Invasive_Species_Data_Protocol.pdf. Accessed 8 November 2018

Publisher's Note Springer Nature remains neutral with regard to jurisdictional claims in published maps and institutional affiliations. 